\title{
IMPLIKASI PENERAPAN PERATURAN PEMERINTAH NOMOR 18 TAHUN 2016 TENTANG ORGANISASI PERANGKAT DAERAH DI PEMERINTAH KOTA YOGYAKARTA
}

\author{
P. Heny Dian Anitasari., S.H., M.Hum \\ Pemerintah Kota Yogyakarta
}

\begin{abstract}
Abstrak
Peraturan Pemerintah No. 18 tahun 2016 telah mengamanatkan Pemerintah Daerah untuk meninjau kembali struktur kelembagaan dan organisasi pemerintahannya. Kondisi yang ada menunjukkan struktur organisasi yang berlebih namun di sisi lain anggaran Pemerintah Daerah terbatas. Penerbitan Peraturan Pemerintah ini diharapkan dapat mewujudkan pemerintahan daerah yang efektifitas dan efisiensi. Setelah diimplementasikan, perlu ada evaluasi kebijakan untuk mengetahui bagaimana dampak atau hasil kebijakan tersebut. Artikel ini diarahkan untuk mengkaji norma hukum positif dan membandingkan realitas restrukturisasi organisasi dan menunjukkan gap antara kondisi yang diharapkan dan kondisi yang ada. Dampak umum terlihat dari terjadinya pembentukan organisasi Pemerintahan Daerah yang homogen yang tercermin dalam kesamaan nomenklatur, bentuk dan jenis. Namun, ada masalah di balik homogenitas tersebut. Implikasinya yang jelas dalam kasus Pemerintah Kota Yogyakarta adalah adanya beberapa urusan pemerintahan tidak diakomodasi dengan baik dan ada peningkatan jumlah unit organisasi Pemerintah Daerah. Dalam urusan pemerintahan, beberapa urusan pemerintahan dengan intensitas sedikit akan digabungkan dengan urusan pemerintahan lainnya dalam struktur kelembagaan. Sedangkan dalam hal anggaran belanja pegawai meningkat karena berbanding lurus dengan kenaikan jumlah eselon II dan eselon III. Kondisi ini juga mempengaruhi penambahan fasilitas infrastruktur kerja yang harus disediakan.
\end{abstract}

Kata kunci : restrukturisasi organisasi, organisasi perangkat daerah, urusan pemerintahan daerah

\begin{abstract}
Government Regulation No. 18 of 2016 has mandated the Regional Government to review its institutional structure and government organization. Existing conditions indicated oversized organizational structure and limited budget of Regional Government. The enactment of this Government Regulation is expected to create effective and efficient Local Government. After being implemented, policy evaluation is necessary to analyze impact or outcome of the policy. This article aims to examine positive legal norms and comparing to the reality of organizational restructuring and demonstrate the gap between expected conditions and existing conditions. A general impact is analyzed from the formation of a homogeneous type of Regional Government organization, reflected in the similarity of nomenclature, form and type. However, there is a problem behind such homogeneity. For the case of Yogyakarta City Government, the obvious implication is that some government affairs are not properly accommodated and there is an increasing number of Regional Government organization units. Based on governmental affairs, low intensity government affairs should be combined with other governmental affairs within an institutional structure. This policy has increased the number of echelon II and echelon III posiition. As a result, personnel expenditure budget increased due to increasing number of echelon I and II. Consequently, work infrastructure and facilities that must be provided increased accordingly.
\end{abstract}

Keywords : organizational restructuring, regional government unit, local government affairs 


\section{A. Latar Belakang}

Perubahan regulasi terkait dengan organisasi perangkat daerah melalui Peraturan Pemerintah (PP) Nomor 18 Tahun 2016 tentang Organisasi Perangkat Daerah (PP 18 Tahun 2016) mengharuskan daerah-daerah otonom (kabupaten/kota) untuk meninjau kembali struktur kelembagaan dan organisasi pemerintahannya. Secara prinsip PP tersebut membawa perubahan yang cukup mendasar terhadap kelembagaan pemerintah, bahkan banyak pihak yang menganggap kehadiran PP tersebut menegaskan upaya untuk melakukan resentralisasi. PP yang merupakan pengganti dari PP nomor 41 Tahun 2007 tentang Organisasi Perangkat Daerah (PP 41 Tahun 2007) ini setidaknya diterbitkan dengan dua semangat, yaitu semangat untuk mengatasi kesimpangsiuran nomenklatur tupoksi dan rentang kendali kelembagaan daerah sebagaimana diatur dalam PP 41 Tahun 2007 dan semangat untuk membatasi jumlah kelembagaan daerah. Hal ini terlihat dari standarisasi yang secara ketat harus diikuti oleh pemerintah daerah-daerah otonom.

Kesimpangsiuran nomenklatur menjadi perhatian karena selama ini ketidaksesuaian nomenklatur lembaga daerah dengan lembaga pusat telah melahirkan persoalan baik koordinasi maupun masalah keuangan. Demikian juga, beberapa nomenklatur telah menyebabkan ketidakefektifan kinerja unit-unit instansi di daerah. Sementara itu, semangat untuk membatasi jumlah kelembagaan daerah lebih didasarkan pada alasan-alasan rasionalitas. Sebagaimana diketahui, kelembagaan struktur organisasi pemerintah daerah yang ada saat ini cenderung sangat gemuk sehingga menghisap sebagian besar alokasi APBD untuk belanja aparatur. Akibatnya, agendaagenda penting pemerintah lainnya tidak bisa dilaksanakan secara maksimal karena keterbatasan anggaran. Oleh karena itu, kehadiran PP ini diharapkan akan menghasilkan penghematan yang sangat signifikan dari pos belanja aparatur sehingga dapat diarahkan untuk pos-pos kegiatan lainnya.

Namun demikian, restrukturisasi organisasi pemerintah daerah juga bukan hal yang mudah. Peraturan ini pada gilirannya juga menciptakan pekerjaan baru bagi daerah sehubungan dengan beberapa konsekuensi besar yang menyertainya, seperti perampingan/penggemukan struktur organisasi perangkat daerah, mutasi PNS, dan lain sebagainya. Beban daerah untuk melakukan restrukturisasi juga semakin berat manakala secara teknis, kebijakan ini mengharuskan dilakukannya restrukturisasi kewenangan dan kelembagaan daerah secara signifikan dalam waktu yang sangat singkat.

Dalam rangka penataan organisasi perangkat daerah, meskipun regulasi menjadi acuan pokok, namun proses restrukturisasi kelembagaan pemerintahan daerah perlu mempertimbangkan banyak aspek, sehingga kelembagaan yang dihasilkan memenuhi idealisme untuk diterapkan. Dalam konteks Pemerintah Kota Yogyakarta ada tiga aspek yang dipertimbangkan sebagai dasar bagi penetapan struktur kelembagaan Kota Yogyakarta, yaitu visi misi, dinamika kota, dan dimensi ideal.

Visi dan misi ke depan Kota Yogyakarta telah ditetapkan dalam rencana strategis. Kelembagaan dalam konteks ini dipahami sebagai instrumen yang dimiliki oleh pemerintah kota untuk melaksanakan visi dan misi pembangunan yang ingin dicapai dalam periode tertentu. Visi dan misi pemerintahan akan bisa dipenuhi bilamana kelembagaan yang dirancang mencerminkan kebutuhan kota untuk melaksanakan prioritas pemerintahan dan pembangunan yang ditetapkan.

Dimensi dinamika kota, yaitu tuntutan masyarakat yang khas, yang membedakan sebuah kota dengan sebuah kabupaten, atau desa, yang dinamikanya bisa dikatakan berbeda dengan kota. Pemerintah daerah tidak bisa lagi menutup mata terhadap dinamika di luar dirinya, 
karenanya ia dituntut responsif dan peka terhadap apa yang berlangsung di sekitarnya. Wujud riil dari kepekaan ini ditunjukkan dalam struktur pemerintah daerah yang memang mampu menjawab kebutuhan masyarakat yang tinggal di wilayah teritorialnya.

Aspek lain yang perlu dipertimbangkan dalam pemikiran restrukturisasi Kota Yogyakarta adalah dimensi ideal sebuah organisasi, yakni yang mengedepankan prinsip efektivitas dan efisiensi. Lembaga yang efektif dan efisien adalah ketika tidak terjadi overlapping dan pada saat yang sama mampu mencapai hasil optimal dari apa yang telah direncanakan sebelumnya.

Proses restrukturisasi juga berada dalam konteks makro lain, seperti konteks yuridis, politis, ekonomis, dan SDM. Konteks makro tersebut pada saat yang bersamaan dapat dibaca sebagai peluang dan tantangan. Meskipun dimaksudkan untuk memenuhi kebutuhan lokal, restrukturisasi kelembagaan Kota Yogyakarta, bagaimana pun juga harus mempertimbangkan aturan main yang telah ditetapkan oleh Pemerintah Nasional. Penataan kelembagaan Kota Yogyakarta perlu mempertimbangkan sejauh mana akan munculnya resistensi yang mungkin dilakukan oleh aparat birokrasi sendiri. Selain itu, faktor penting yang harus diperhatikan adalah pertimbangan kemampuan pemerintah kota dalam pembiayaan atas hasil restrukturisasi, agar jangan sampai aktivitas yang dimaksudkan untuk mengoptimalkan format kelembagaan, justru akan berujung pada pemborosan keuangan daerah.

Dalam hal ini, Pemerintah Kota Yogyakarta memiliki kewajiban untuk menyesuaikan dan menerjemahkan secara konkret urusan pemerintahan tersebut. Hal tersebut tentu bukan merupakan perkara yang mudah. Pada satu sisi, pemerintah kota dituntut untuk melakukan penyesuaian dan perubahan kelembagaan organisasi perangkat daerah dalam rangka tertib dan taat peraturan perundang-undangan dan kepastian hukum (rule driven), sedangkan pada sisi yang lain, hal tersebut tidak jarang berakibat pada terganggunya sistem birokrasi pemerintahan yang selama ini telah menerjemahkan dengan baik kebutuhan-kebutuhan yang ada di daerah.

Permasalahan dalam tulisan ini adalah bagaimana implikasi kebijakan penataan organisasi Perangkat Daerah berdasarkan PP Nomor 18 Tahun 2016 di Pemerintah Kota Yogyakarta? Adapun tujuan tulisan adalah untuk menganalisis implikasi yang timbul dari kebijakan restrukturisasi organisasi perangkat daerah.

\section{B. Kerangka Teori}

Secara teoritik beberapa konsep dipergunakan sebagai pijakan dalam melakukan analisa kelembagaan dan penyusunan arah rekomendasi kebijakan. Beberapa konsep tersebut adalah sebagai berikut:

\section{a. Otonomi dan Desentralisasi}

Otonomi daerah adalah hak, wewenang, dan kewajiban daerah otonom untuk mengatur dan mengurus sendiri urusan pemerintahan dan kepentingan masyarakat setempat sesuai dengan peraturan perundang-undangan. Otonomi daerah merupakan sistem pemerintahan yang sekarang ini menjadi pilihan, terutama untuk mengatur hubungan antara pusatdaerah di Indonesia. Seperti tercatat dalam sejarah, masalah relasi pusat-daerah merupakan isu sensitif yang banyak menimbulkan persoalan. Kekecewaan daerah yang muncul belakangan ini sebagai akibat dari penerapan sistem sentralistis sebetulnya bukan peristiwa baru. Dipilihnya desentralisasai sebagai asas otonomi daerah dalam pengelolaan pemerintahan merupakan pilihan tepat karena secara teoritis mempunyai banyak keunggulan. Menurut Osborne dan Gaebler (Reinventing Government, Reading, MA.: Plume, 1993), keunggulan-keunggulan lembaga yang terdesentralisasi adalah: 
1. Lembaga yang terdesentralisasi jauh lebih fleksibel, sehingga dapat memberi respon yang cepat terhadap lingkungan dan kebutuhan pelanggan (masyarakat) yang berubah.

2. Lembaga yang terdesentralisasi jauh lebih efektif daripada yang tersentralisasi.

3. Lembaga yang terdesentralisasi jauh lebih inovatif daripada yang tersentralisasi.

4. Lembaga yang terdesentralisasi menghasilkan semangat kerja yang lebih tinggi, lebih banyak komitmen, dan lebih produktif.

Sedangkan bagi dunia ketiga, termasuk Indonesia, desentralisasi pemerintahan adalah sebuah kebutuhan. Berkaitan dengan hal tersebut, Cheema dan Rondinelli (1983 : 14-16) merangkum sejumlah argumen yang berkaitan dengan pentingnya desentralisasi di dunia ketiga. Khusus berkaitan langsung dengan isu penataan kelembagaan, argumentasi pentingnya pelaksanaan desentralisasi di negara-negara dunia ketiga didasarkan atas pertimbangan sebagai berikut:

1. Desentralisasi memungkinkan pemerintahan di tingkat lokal untuk membuat program-program dan rencana pembangunan sesuai dengan kebutuhan daerah dan masyarakat.

2. Desentralisasi yang berarti transfer kekuasaan dari tingkat pusat ke daerah, akan dapat meningkatkan sensitivitas aparat pemerintahan terhadap persoalan-persoalan yang dihadapi masyarakat.

3. Desentralisasi dapat mendorong peningkatan kapabilitas pemerintahan dan institusi-institusi swasta (private) di tingkat lokal. Desentralisasi juga mendorong aparat di tingkat lokal untuk meningkatkan kemampuan teknis dan manajerialnya.

4. Struktur pemerintahan yang terdesentralisasi diperlukan untuk melembagakan partisipasi masyarakat dalam perencanaan dan pengelolaan pembangunan.
5. Desentralisasi memungkinkan penciptaan sistem administrasi yang lebih fleksibel, kreatif, dan inovatif.

Dengan demikian pemerintahan yang terdesentralisasi menyediakan ruang bagi daerah untuk melakukan inovasi-inovasi dalam penataan lembaganya sesuai dengan potensi dan beban yang ditanggung. Persoalan pelayanan publik juga akan bisa lebih baik dilakukan, karena daerah sendirilah yang mengetahui persoalan di lingkungannya.

\section{Metodologi}

Tulisan ini merupakan kajian hukum normatif, artinya kajian ini dikaji norma-norma hukum positif dalam menggambarkan realitas yang ada, untuk selanjutnya membandingkan antara normanorma hukum positif dengan kenyataan restrukturisasi organisasi kelembagaan perangkat daerah. Metode pendekatan yang digunakan adalah yuridis historis, yaitu data yang terkumpul didekati dengan pendekatan sejarah hukumnya. Penilaian terhadap peristiwa-peristiwa hukum diukur dari sejarah hukum.

Bahan penelitian dalam penelitian hukum normatif terdiri dari bahan hukum primer dan bahan hukum sekunder (Maria, 1989: 7) dengan rincian sebagai berikut :

1. Bahan Hukum Primer

Bahan hukum yang berupa dokumen dan arsip-arsip resmi organisasi perangkat daerah Pemerintah Kota Yogyakarta dan peraturan perundangan yang berlaku, yaitu:

a. Peraturan Pemerintah Nomor 41 Tahun 2007 tentang Pedoman Organisasi Perangkat Daerah;

b. Peraturan Pemerintah Nomor 18 Tahun 2016 tentang Organisasi Perangkat Daerah;

c. Peraturan Daerah Kota Yogyakarta Nomor 5 Tahun 2016 tentang Susunan dan Kedudukan Organisasi Perangkat Daerah. 
2. Bahan Hukum Sekunder

Bahan-bahan hukum yang memberikan penjelasan mengenai bahan hukum primer, yang terdiri dari literatur-literatur seperti: buku, bahan seminar, makalah dan lain-lain yang terkait dengan obyek penelitian.

\section{Data yang telah terkumpul} dianalisis secara normatif kualitatif. Normatif karena penelitian ini bertitik tolak dari peraturan perundang-undangan yang ada sebagai norma positif. Analisis kualitatif dilakukan dengan menganalisis paparan hasil penelitian yang sudah tersistematis tersebut dengan yang didapat dari teori-teori hukum, serta hukum positif (in concreto), untuk dapat menjelaskan permasalahan penelitian hukum tersebut dalam bentuk kalimat yang bisa dipahami secara ilmiah, bukan dalam bentuk angkaangka atau data statistik.

\section{Hasil Dan Pembahasan}

Kebijakan desentralisasi dan otonomi daerah membawa implikasi penyerahan kewenangan dari pusat kepada daerah. Kewenangan yang telah dilimpahkan kepada daerah ini diakomodasi melalui kelembagaan perangkat daerah sesuai prinsip structure follows function. Kewenangan merupakan dasar kelembagaan, sedangkan kelembagaan merupakan wadah untuk melaksanakan kewenangan. Hadirnya PP Nomor 18 Tahun 2016 tentang Perangkat Daerah merupakan amanat dari UU Nomor 23 Tahun 2014 untuk menerbitkan Peraturan Daerah tentang kedudukan, susunan organisasi, rincian tugas dan fungsi, serta tata kerja perangkat daerah.

Terkait hal tersebut, Pemerintah Kota Yogyakarta memiliki kewajiban menyesuaikan dan menerjemahkan urusan pemerintahan konkuren yang merupakan jatah kabupaten/kota ke dalam tata kelembagaan yang tidak bertentangan dengan ketentuan normatif lainnya, yaitu produk perundang-undangan di atasnya.
Tantangan yang dihadapi dalam pembentukan organisasi perangkat daerah adalah pertama, struktur organisasi harus efektif dan efisien dalam mewadahi urusanurusan pemerintahan sesuai prinsip tepat fungsi dan tepat ukuran (rightsizing) berdasarkan beban kerja yang sesuai dengan kondisi nyata di masing-masing daerah. Kedua, orientasi pegawai daerah adalah menduduki jabatan yang lebih tinggi sehingga hal ini mendorong untuk memperbesar struktur birokrasi yang mampu menampung banyak pejabat birokrasi. Berbagai tantangan yang dihadapi organisasi perangkat daerah pada akhirnya akan menentukan kinerja daerah. Maka dari itu perlu memperhatikan desain, struktur, mekanisme kerja, dan kualitas aparatur.

Pada bagian ini ditujukan untuk menganalisis peraturan perundangan yang terkait dengan kelembagaan di level pusat dan daerah yang sesuai dengan konteks Kota Yogyakarta. Analisis dilakukan untuk melihat kesesuaian antara regulasi yang ada dengan konteks kebutuhan dan kekhasan daerah. Secara singkat bagian ini akan membahas, pertama, pembagian urusan pemerintahan antara pusat dan daerah yang tercantum dalam PP Nomor 18 Tahun 2016. Kedua, wadah kelembagaan yang dapat dibentuk untuk mengakomodir urusan-urusan Pemerintahan Kota Yogyakarta berdasarkan PP Nomor 18 Tahun 2016.

\section{a. Urusan PP 18 Tahun 2016}

Dalam PP Nomor 18 Tahun 2016, perangkat daerah kabupaten/kota terdiri atas: Sekretariat Daerah, Sekretariat DPRD, Inspektorat, Dinas, Badan, dan Kecamatan. Pembentukan perangkat daerah mempertimbangkan faktor luas wilayah, jumlah penduduk, kemampuan keuangan daerah serta besaran beban tugas sesuai dengan urusan pemerintahan daerah yang diserahkan kepada daerah. Sedangkan PP Nomor 41 Tahun 2007, perangkat daerah kabupaten/kota terdiri dari Sekretariat 
Daerah, Sekretariat DPRD, Inspektorat, Dinas, Lembaga Teknis Daerah, Kecamatan, dan Kelurahan.

Tabel 1

Perbandingan PP Nomor 41 Tahun 2007 dan PP Nomor 18 Tahun 2016

\begin{tabular}{|c|c|c|}
\hline Perihal & PP 41 Tahun 2007 & PP 18 Tahun 2016 \\
\hline $\begin{array}{l}\text { Pertimbangan } \\
\text { pembentukan } \\
\text { OPD }\end{array}$ & \begin{tabular}{|ll} 
a. & $\begin{array}{l}\text { Kewenangan } \\
\text { pemerintahan yang } \\
\text { dimiliki oleh daerah }\end{array}$ \\
b. & Karakteristik, \\
potensi \\
dan kebutuhan \\
daerah \\
c. \\
Kemampuan \\
deuangan daerah \\
d. & $\begin{array}{l}\text { Ketersediaan } \\
\text { sumber daya }\end{array}$ \\
e. & Aparatur \\
e. & $\begin{array}{l}\text { Pengembangan pola } \\
\text { kerja sama (antar } \\
\text { daerah dan/atau } \\
\text { pihak ketiga) }\end{array}$
\end{tabular} & 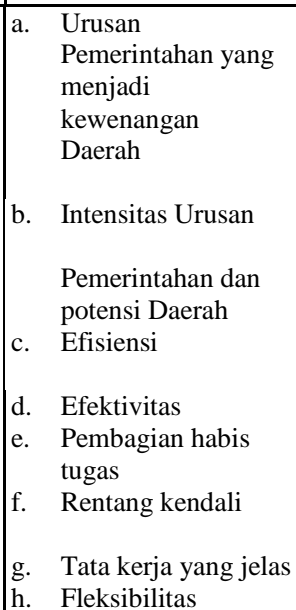 \\
\hline \begin{tabular}{|l|} 
Perangkat \\
daerah \\
Kabupaten/Kota
\end{tabular} & \begin{tabular}{|ll} 
a. & Sekretariat Daerah \\
b. & Sekretariat DPRD \\
c. & Inspektorat \\
d. & BAPPEDA \\
e. & Dinas \\
f. & Lembaga Teknis \\
& Daerah (badan, \\
& dinas, dan rumah \\
& sakit) \\
g. & Kecamatan \\
h. & Kelurahan
\end{tabular} & \begin{tabular}{|ll} 
a. & Sekretrariat Daerah \\
b. & Sekretariat DPRD \\
c. & Inspektorat \\
d. & Dinas A/B/C \\
e. & Badan A/B/C \\
f. & Kecamatan A/B
\end{tabular} \\
\hline
\end{tabular}

Urusan pemerintahan yang telah diserahkan kepada kabupaten/kota pada akhirnya harus diterjemahkan ke dalam wadah kelembagaan daerah. Untuk lebih lanjut membentuk lembaga yang sesuai dengan tipologi perangkat daerah, terlebih dahulu perlu melakukan pemetaan urusan pemerintahan berdasarkan variabel beban kerja yang terdiri dari variabel umum dan variabel teknis.

Pada pasal 6, PP Nomor 18 Tahun 2016 dijelaskan bahwa variabel umum bobot sebesar $20 \%$ yang dilihat melalui indikator jumlah penduduk; luas wilayah; dan jumlah anggaran pendapatan dan belanja Daerah. Sedangkan variabel teknis bobot $80 \%$ yang didasarkan pada beban tugas utama pada setiap urusan pemerintahan yang menjadi kewenangan daerah.
Pada prinsipnya, masing-masing urusan pemerintahan diwadahi dalam satu satuan kerja perangkat daerah. Namun apabila intensitas urusan pemerintahan tersebut kecil maka penyelenggaraan fungsi urusan tersebut digabung dengan perangkat daerah yang memiliki kedekatan karakteristik dan/atau keterkaitan fungsi urusan pemerintahan tersebut. Perumpunan urusan pemerintahan untuk kabupaten/kota yaitu meliputi:

a. Pendidikan, kebudayaan, kepemudaan dan olahraga, serta pariwisata.

b. Kesehatan, sosial, pemberdayaan perempuan dan perlindungan anak, pengendalian penduduk dan keluarga berencana, administrasi kependudukan dan pencatatan sipil, serta pemberdayaan masyarakat dan desa.

c. Ketenteraman, ketertiban umum dan perlindungan masyarakat, sub urusan ketenteraman dan ketertiban umum dan sub urusan kebakaran.

d. Penanaman modal, koperasi, usaha kecil dan menengah, perindustrian, perdagangan, energi dan sumber daya mineral, transmigrasi, dan tenaga kerja.

e. Komunikasi dan informatika, statistik dan persandian.

f. Perumahan dan kawasan permukiman, pekerjaan umum dan penataan ruang, pertanahan, perhubungan, lingkungan hidup, kehutanan, pangan, pertanian, serta kelautan dan perikanan.

g. Perpustakaan dan kearsipan.

Apabila dalam penyusunan organisasi perangkat daerah hanya mendasarkan pada variabel umum, variabel khusus seperti yang tertuang dalam PP Nomor 18 Tahun 2016 tersebut tanpa memperhatikan konteks lokalitas daerah, maka yang akan terjadi dalam pembentukan organisasi perangkat daerah tersebut akan terjadi kecenderungan yang sama (homogen). Apabila melihat urusan yang ada di PP Nomor 18 Tahun 2016, maka tidak semua urusan yang ada di Pemerintah Kota Yogyakarta dapat 
terwadahi dalam struktur kelembagaan. beberapa tugas dinas yang sudah berjalan tidak terakomodasi seperti Dinas Perizinan, Dinas Pengelolaan Pasar, Dinas Bangunan Gedung dan Aset Daerah, serta Kantor Pengelolaan Taman Pintar.

\section{b. Wadah Kelembagaan Pemerintah Kota Yogyakarta}

Pemikiran di bidang inovasi penyelenggaraan birokrasi dikembangkan, secara populer antara lain yang populer adalah konsep inovasi birokrasi Osborne dan Gaebler (1995), yang mentransformasikan 10 prinsip kewirausahaan ke dalam organisasi publik, melaksanakan perubahan-perubahan dalam pemerintahan yang dikenal dengan istilah Reinventing Government atau Mewirausahakan Birokrasi, yaitu:

1. Pemerintahan Katalis: Mengarahkan Ketimbang Mengayuh. Pemerintah lebih mengkonsentrasikan diri pada aspek pengaturan/regulasi dengan membuat kebijaksanaan daripada sebagai pelaksana kebijakan atau pelaksana penyelenggaraan pelayanan umum bagi masyarakat;

2. Pemerintahan Milik Masyarakat: Memberi Wewenang Ketimbang Melayani. Pemerintah lebih bertujuan kepada memberdayakan masyarakat (empowering citizens) tidak hanya melayani yang membuat masyarakat terlena dan tergantung kepada pemerintah tetapi pemberian layanan dan penyediaan fasilitas dilakukan dalam rangka pendewasaan dan pemandirian masyarakat;

3. Pemerintahan yang Kompetitif: Menyuntikkan Persaingan ke dalam Pemberian Pelayanan. Menciptakan kompetisi dalam pemerintahan dengan mendorong terjadinya kompetisi dalam pemberian layanan di antara penyelenggara pelayanan umum;

4. Pemerintahan yang Digerakkan oleh Misi: Mengubah Organisasi yang Digerakkan oleh Peraturan.
Pemerintah atau birokrasi Max Weber mengemukakan bahwa jalannya birokrasi dikendalikan atau diarahkan oleh aturan, konsepsi tersebut dirasakan kurang tepat lagi tetapi sebaiknya Pemerintah atau birokrasi berjalan diarahkan oleh tujuan dan misi (mission) yang telah ditetapkan yakni untuk kepentingan masyarakat;

5. Pemerintahan yang Berorientasi pada Hasil: Membiayai Hasil, bukan Masukan. Pemerintah yang berorientasi pada hasil dengan penekanan atau pokok perhatian bukan ada aspek "inputs", melainkan pada aspek hasilnya (outcomes);

6. Pemerintahan Berorientasi Pelanggan: Memenuhi Kebutuhan Pelanggan, Bukan Birokrasi. Pemerintah yang diarahkan oleh kebutuhan dari konsumen yaitu masyarakat bukan diarahkan oleh kebutuhan daripada birokrasi;

7. Pemerintahan Wirausaha: Menghasilkan Ketimbang Membelanjakan. Penanaman semangat wirausaha dalam Pemerintah, yakni bersemangat untuk menghasilkan atau mendapatkan keuntungan untuk penerimaan keuangan, daripada memikirkan bagaimana menghabiskan anggaran yang dialokasikan;

8. Pemerintahan Antisipatif: Mencegah daripada Mengobati. Pemerintah yang antisipatif, yakni melakukan antisipasi baik berupa pencegahan terjadinya sesuatu permasalahan, antisipasi terhadap perubahan yang mungkin akan terjadi, daripada mengatasi masalah setelah permasalahan tersebut muncul atau menyesuaikan setelah perubahan terjadi;

9. Pemerintahan Desentralisasi: Merubah Hirarki kepada Partisipasi dan Kerjasama. Pemerintah yang melaksanakan desentralisasi atau mendelegasikan kewenangan kepada unsur-unsur bawahannya antara lain dengan menerapkan pola manajemen partisipatif serta kerjasama kelompok 
(teamwork) dalam pencapaian sasaran organisasi.

10. Pemerintahan Berorientasi Pasar: Mendongkrak Perubahan Melalui Pasar. Pemerintah yang mendorong berlakunya "mekanisme pasar" secara sehat dan menyesuaikan tuntutan perubahan berdasarkan tuntutan dan mekanisme pasar.

Dari sepuluh prinsip tersebut menunjukkan pola yang dikembangkan dalam sistem birokrasi yang menganut kultur positif untuk menjadi sebuah birokrasi yang lebih berorientasi pada pelayanan. Jika prinsip-prinsip tersebut dapat secara komprehensif diimplementasikan maka akan berhasil membentuk refungsionalisasi birokrasi sehingga birokrasi yang "melayani" benar-benar dapat diwujudkan. Sementara itu strategic apex memberikan sentuhan dalam kebijakan yang menekankan perlunya perubahan kultur serta mengkondisikan organisasi untuk mengimplementasikan pola pelayanan.

Terkait dengan disain organisasi yang dilakukan hendaknya menganut beberapa ketentuan mendasar, yaitu rule driven, mission driven, function driven, potential driven (Sulistiyani, 2011). Artinya sebuah penataan kelembagaan pemerintah dalam disain organisasi senantiasa memperhatikan, mempertimbangkan dan mengikuti ketentuan perundang-undangan, sesuai dengan visi dan misi daerah dan memperhatikan fungsifungsi utama organisasi serta potensi daerah. Bittner (1965), mengemukakan bahwa perdebatan di seputar permasalahan analisis struktural-fungsional menunjukkan secara meyakinkan bahwa desain administratif formal tidak pernah mengacu pada organisasi kaku, karena sesungguhnya tetap memperhatikan masalah relevansi dalam studi sosiologis organisasi. Desain organisasi mengikuti konsepsi tertentu yang memenuhi kebutuhan teknis manajemen.
Bakker (2008) dalam menghadapi realitas seperti itu berargumen bahwa gagasan pemikiran strategis muncul untuk mengisi kesenjangan dan mengatasi keterbatasan. Organisasi yang melakukan perencanaan strategis telah terbukti menunjukkan kinerja yang lebih baik. Hasil pemikiran strategis bersifat jangka panjang. Dua fokus dalam pemikiran strategis secara umum adalah perencanaan ke atas terfokus melihat memastikan bagaimana taktik menghubungkan ke tujuan organisasi, pemikiran strategis ke bawah terfokus memastikan bahwa makna dan tujuan yang ingin dicapai telah disebarkan ke seluruh organisasi sehingga pencapaian tujuan dan taktik yang tepat dapat dikembangkan untuk memenuhi kebutuhan riil organisasi.

Menurut Fauzan (2016) bahwa PP 18 Tahun 2016 sebagai pengganti PP Nomor 41 tahun 2007 secara esensial bahwa perubahan terletak pada rekognisi pembagian urusan pemerintahan yang berkorelasi pada kewenangan dan basis penataan organisasi perangkat daerah. Dalam PP Nomor 18 Tahun 2016, daerah dalam penataan kelembagaan organisasi perangkat daerah semuanya telah diatur sedemikian rupa, sehingga nomenklatur, bentuk dan besaran organisasi diharapkan seragam di seluruh Indonesia, dengan harapan untuk lebih memudahkan koordinasi antara Pemerintah Pusat dan Pemerintah Daerah

Khusus untuk Kota Yogyakarta, permasalahannya bertambah ketika kondisi existing terdapat beberapa OPD yang merupakan inovasi Pemerintah Kota Yogyakarta, antara lain Dinas Perizinan, Dinas Pengelolaan Pasar dan Kantor Pengelolaan Taman Pintar. Nomenklatur kelembagaan yang dibiarkan tanpa penyesuaian ini, nantinya akan menghambat urusan koordinasi dengan pemerintah pusat baik dalam sharing informasi, kerjasama jaringan, maupun fasilitas sumberdaya dan pendanaan. Tetapi pada saat yang sama ada kebutuhan dan konteks lokal daerah Kota Yogyakarta yang memiliki kekhasan, sehingga "kepatuhan" 
terhadap regulasi pusat memang tidak dapat menjadi satu-satunya rujukan dalam penataan dan pengembangan kelembagaan perangkat daerah. Berdasarkan Peraturan Daerah Kota Yogyakarta Nomor 5 Tahun 2016 tentang Susunan, Kedudukan Organisasi Perangkat Daerah, Organisasi Perangkat Daerah yang dibentuk sudah tidak lagi mencerminkan inovasi kelembagaan yang pernah dilakukan pada tahun 2007.

Tabel 2

Perbandingan OPD menurut PP 41 Tahun 2007 dan PP No 18 Tahun 2016

\begin{tabular}{|c|c|c|}
\hline NO & $\begin{array}{c}\text { ORGANISASI } \\
\text { PERANGKAT DAERAH } \\
\text { BERDASARKAN PP 41/ } \\
\quad 2007\end{array}$ & $\begin{array}{c}\text { ORGANISASI } \\
\text { PERANGKAT } \\
\text { DAERAH } \\
\text { BERDASARKAN PP } \\
\text { 18/ } 2016 \\
\end{array}$ \\
\hline 1. & Sekretariat DPRD & Sekretariat DPRD \\
\hline 2. & Sekretariat Daerah : & Sekretariat Daerah : \\
\hline $\mathbf{A}$ & Asisten Pemerintahan & $\begin{array}{l}\text { Asisten Kesejahteraan } \\
\text { Rakyat }\end{array}$ \\
\hline 1. & Bagian Tata Pemerintahan & $\begin{array}{l}\text { Bagian Tata } \\
\text { Pemerintahan }\end{array}$ \\
\hline 2. & Bagian Hukum & Bagian Hukum \\
\hline 3. & Bagian Organisasi & \\
\hline $\mathbf{B}$ & $\begin{array}{l}\text { Asisten Perekonomian dan } \\
\text { Pembangunan } \\
\end{array}$ & Asisten Perekonomian \\
\hline 1. & $\begin{array}{l}\text { Bagian Perekonomian, } \\
\text { Pengembangan Pendapatan } \\
\text { Asli Daerah dan Kerjasama }\end{array}$ & $\begin{array}{l}\text { Bagian } \\
\text { Perekonomiandan } \\
\text { Kerjasama Daerah } \\
\end{array}$ \\
\hline 2. & $\begin{array}{l}\text { Bagian Pengendalian } \\
\text { Pembangunan }\end{array}$ & $\begin{array}{l}\text { Bagian Administrasi } \\
\text { Pembangunan }\end{array}$ \\
\hline 3. & $\begin{array}{l}\text { Bagian Teknologi Informasi } \\
\text { dan Telematika }\end{array}$ & $\begin{array}{l}\text { Bagian Layanan } \\
\text { Pengadaan }\end{array}$ \\
\hline C. & $\begin{array}{l}\text { Asisten Administrasi } \\
\text { Umum }\end{array}$ & Asisten Administrasi \\
\hline 1. & Bagian Humas dan Informasi & Bagian Organisasi \\
\hline 2. & Bagian Protokol & Bagian Protokol \\
\hline 3. & Bagian Umum & Bagian Umum \\
\hline & DINAS DAERAH & DINAS DAERAH \\
\hline 1. & Dinas Pendidikan & Dinas Pendidikan \\
\hline 2. & Dinas Kesehatan & Dinas Kesehatan \\
\hline 3. & $\begin{array}{l}\text { Dinas Sosial, Tenaga Kerja } \\
\text { dan Transmigrasi }\end{array}$ & Dinas Sosial \\
\hline 4. & Dinas Perhubungan & Dinas Perhubungan \\
\hline 5. & $\begin{array}{l}\text { Dinas Kependudukan dan } \\
\text { Pencatatan Sipil }\end{array}$ & $\begin{array}{l}\text { Dinas Kependudukan } \\
\text { dan Pencatatan Sipil }\end{array}$ \\
\hline 6. & $\begin{array}{l}\text { Dinas Pariwisata dan } \\
\text { Kebudayaan }\end{array}$ & Dinas Pariwisata \\
\hline 7. & $\begin{array}{l}\text { Dinas Permukiman dan } \\
\text { Prasarana Wilayah }\end{array}$ & Dinas Kebudayaan \\
\hline 8. & $\begin{array}{l}\text { Dinas Perindustrian, } \\
\text { Perdagangan, Koperasi dan } \\
\text { Pertanian }\end{array}$ & $\begin{array}{l}\text { Dinas PU dan } \\
\text { Permukiman }\end{array}$ \\
\hline 9. & $\begin{array}{l}\text { Dinas Pajak Daerah dan } \\
\text { Pengelolaan Keuangan }\end{array}$ & $\begin{array}{l}\text { Dinas Pertanahan dan } \\
\text { Tata Ruang }\end{array}$ \\
\hline 10. & Dinas Perizinan & $\begin{array}{l}\text { Dinas Perindustrian dan } \\
\text { Perdagangan }\end{array}$ \\
\hline 11. & Dinas Pengelolaan Pasar & $\begin{array}{l}\text { Dinas Koperasi, UMKM } \\
\text { dan Tenaga Kerja }\end{array}$ \\
\hline
\end{tabular}

\begin{tabular}{|c|c|c|}
\hline 12. & Dinas Ketertiban & $\begin{array}{l}\text { Dinas Penanaman Modal } \\
\text { dan Perizinan }\end{array}$ \\
\hline 13. & $\begin{array}{l}\text { Dinas Bangunan Gedung dan } \\
\text { Aset Daerah }\end{array}$ & $\begin{array}{l}\text { Satuan Polisi Pamong } \\
\text { Praja }\end{array}$ \\
\hline 14 & & Dinas Lingkungan Hidup \\
\hline 15 & & $\begin{array}{l}\text { Dinas Kominfo dan } \\
\text { Persandian }\end{array}$ \\
\hline 16 & & $\begin{array}{l}\text { Dinas Pemeberdayaan } \\
\text { Masyarakat, Perempuan } \\
\text { dan Anak }\end{array}$ \\
\hline 17 & & $\begin{array}{l}\text { Dinas Kearsipan dan } \\
\text { Perpustakaan }\end{array}$ \\
\hline 18 & & $\begin{array}{l}\text { Dinas Pertanian dan } \\
\text { Pangan }\end{array}$ \\
\hline 19 & & $\begin{array}{l}\text { Dinas Pengendalian } \\
\text { Penduduk dan KB }\end{array}$ \\
\hline 20 & & $\begin{array}{l}\text { Dinas Kependudukan \& } \\
\text { Pencatatan Sipil }\end{array}$ \\
\hline 21 & & $\begin{array}{l}\text { Dinas Pemuda dan olah } \\
\text { raga }\end{array}$ \\
\hline & $\begin{array}{l}\text { LEMBAGA TEKNIS } \\
\text { DAERAH } \\
\end{array}$ & $\begin{array}{c}\text { LEMBAGA TEKNIS } \\
\text { DAERAH }\end{array}$ \\
\hline 1. & Inspektorat & Inspektorat \\
\hline 2. & $\begin{array}{l}\text { Badan Perencanan } \\
\text { Pembangunan Daerah }\end{array}$ & $\begin{array}{l}\text { Badan Perencanan } \\
\text { Pembangunan Daerah }\end{array}$ \\
\hline 3. & Badan Kepegawaian Daerah & $\begin{array}{l}\text { Badan Kepegawaian } \\
\text { Pendidikan dan Pelatihan }\end{array}$ \\
\hline 4. & Badan Lingkungan Hidup & RSUD \\
\hline 5. & RSUD & $\begin{array}{l}\text { Badan Pengelolaan } \\
\text { Pajak, Keuangan dan } \\
\text { Aset Daerah }\end{array}$ \\
\hline 6. & Kantor Kesatuan Bangsa & Kantor Kesatuan Bangsa \\
\hline 7. & $\begin{array}{l}\text { Kantor Pengelolaan Taman } \\
\text { Pintar }\end{array}$ & BPBD \\
\hline 8. & BPBD & \\
\hline 9. & $\begin{array}{l}\text { Kantor Arsip dan } \\
\text { Perpustakaan Daerah }\end{array}$ & \\
\hline 10. & $\begin{array}{l}\text { Kantor Pemberdayaan } \\
\text { Masyarakat dan Perempuan }\end{array}$ & \\
\hline \multirow[t]{2}{*}{11.} & Kantor Keluarga Berencana & \\
\hline & $\begin{array}{l}\text { KECAMATAN dan } \\
\text { KELURAHAN } \\
\end{array}$ & $\begin{array}{l}\text { KECAMATAN dan } \\
\text { KELURAHAN }\end{array}$ \\
\hline
\end{tabular}

Berdasarkan perbandingan jumlah OPD, maka jumlah OPD Pemerintah Kota Yogyakarta mengalami penambahan jumlah, hal ini berdampak pula pada besaraan tunjangan yang harus diberikan karena untuk Dinas dan Badan semuanya adalah eselon II, hal ini yang tidak diperhitungan dalam PP 18 tahun 2016, bahwa pembedaan Dinas dan Badan tipe $\mathrm{A} / \mathrm{B} / \mathrm{C}$ tidak diimbangi dengan kelas jabatan.

Tabel 3

Perbandingan Jabatan Struktural menurut PP 41

Tahun 2007 dan PP No 18 Tahun 2016

\begin{tabular}{|c|c|c|c|c|c|c|c|c|c|}
\hline \multicolumn{4}{|c|}{ PP NO 41 TAHUN 2007 } & \multicolumn{5}{c|}{ PP NO 18 TAHUN 2016 } \\
\hline ES II & ES III & ES IV & ES V & TOTAL & ES II & ES III & ES IV & ES V & TOTAL \\
\hline 26 & 138 & 680 & 16 & 860 & 34 & 176 & 589 & - & 799 \\
\hline
\end{tabular}

Sumber: Bagian Organisasi 2017 
Berdasarkan data mengenai jumlah jabatan struktural yang ada, di mana jumlah jabatan tersebut sebanyak 799 belum termasuk dalam hitungan pejabat yang melaksanakan tugas di Unit Pelaksana Teknis Daerah, karena sampai dengan saat ini belum dilaksanakan pelantikan pejabat strukturalnya. Dengan adanya penambahan jumlah jabatan ini, maka dalam penataan pegawai harus dipikirkan kompetensi dan kapasitas sumber daya aparatur yang ada. Di mana saat ini Pemerintah Kota Yogyakarta dalam pemenuhan jumlah SDM di setiap SKPD maksimal hanya $50 \%$ dari hasil analisa jabatan. Sehingga dimungkinkan adanya pejabat struktural yang tidak mempunyai staf.

Pertambahan jumlah jabatan struktural ini juga berimplikasi pada penambahan beban anggaran belanja pegawai, sehingga rasio $50 \%$ anggaran pelanja pegawai dari total APBD Kota Yogyakarta tidak akan tercapai. Serta penambahan sarana prasarana baik itu berupa kendaraan dinas jabatan maupun kendaraan dinas operasional.

Sebagai pembanding kabupaten lain di Daerah Istimewa Yogyakarta yang mengalami kenaikan jumlah jabatan struktural adalah Kabupaten Sleman. Pembentukan Perangkat Daerah ditetapkan dengan Peraturan Daerah Kabupaten Sleman Nomor 11 Tahun 2016 tentang Pembentukan dan Susunan perangkat Daerah Kabupaten Sleman. Berdasarkan peraturan daerah tersebut jumlah pejabat struktural yang ada, sebagai berikut:

Tabel 4

Perbandingan jabatan Struktural Kabupaten Sleman

\begin{tabular}{|c|c|c|c|}
\hline Eselon & $\begin{array}{c}\text { Tahun } \\
\mathbf{2 0 1 5}\end{array}$ & $\begin{array}{c}\text { Tahun } \\
\mathbf{2 0 1 7}\end{array}$ & Selisih \\
\hline II a & 1 & 1 & 0 \\
\hline II b & 31 & 35 & +4 \\
\hline III a & 57 & 61 & +4 \\
\hline III b & 95 & 117 & +22 \\
\hline IV a & 468 & 510 & +42 \\
\hline IV b & 123 & 111 & -12 \\
\hline V a & 71 & 0 & -71 \\
\hline & 846 & 835 & -11 \\
\hline
\end{tabular}

Sumber: Bagian Organisasi Kab. Sleman 2017
Berdasarkan hasil analisis di atas, maka implikasi yang ada kaitannya dengan penerapan PP No. 18 Tahun 2016, adalah:

1. Tidak semua urusan yang ada di pemerintah Kota Yogyakarta dapat terwadahi dalam struktur kelembagaan. Beberapa tugas dinas yang sudah berjalan tidak terakomodasi seperti Dinas Perizinan, Dinas Pengelolaan Pasar, Dinas Bangunan Gedung dan Aset Daerah, Kantor Pengelolaan Taman Pintar, dan Rumah Sakit Umum Daerah. Aturan terkesan memaksakan untuk memasukan fungsi yang tidak terakomodir perumpunan urusannya.

2. Penambahan jumlah anggaran Belanja Pegawai akibat terjadinya pembengkakan jumlah OPD.

3. Penambahan sarana prasarana akibat terjadinya penambahan jumlah OPD.

4. Kondisi personel birokrat yang belum optimal untuk mengimplementasikan tugas baik dari segi kualitas maupun kuantitas.

\section{Kesimpulan dan Saran}

\section{A. Kesimpulan}

Restrukturisasi kelembagaan perangkat daerah Pemerintah Kota Yogyakarta merupakan bentuk adaptasi lembaga terhadap dinamika zaman, tuntutan masyarakat, serta upaya penyelarasan dengan peraturan perundangan yang bersifat dinamis. Wujud dari restrukturisasi kelembagaan tersebut pada akhirnya menghasilkan pembentukan kelembagaan baru, penggabungan kelembagaan, maupun penyempurnaan nomenklatur. Implikasi yang muncul dari kebijakan penerapan PP 18 Tahun 2016 adalah sebagai berikut:

1. Tidak semua urusan yang ada di Pemerintah Kota Yogyakarta dapat terwadahi dalam struktur kelembagaan. Beberapa tugas dinas yang sudah berjalan tidak terakomodasi seperti Dinas Perizinan, Dinas Pengelolaan Pasar, Dinas 
Bangunan Gedung dan Aset Daerah, Kantor Pengelolaan Taman Pintar, dan Rumah Sakit Umum Daerah. Aturan terkesan memaksakan untuk memasukan fungsi yang tidak terakomodir perumpunan urusannya.

2. Penambahan jumlah anggaran Belanja Pegawai akibat terjadinya pembengkakan jumlah OPD.

3. Penambahan sarana prasarana akibat terjadinya penambahan jumlah OPD.

4. Kondisi personel birokrat yang belum optimal untuk mengimplementasikan tugas baik dari segi kualitas maupun kuantitas.

\section{B. Rekomendasi Kebijakan}

Dari hasil analisis yang dilakukan, penataan kelembagaan Kota Yogyakarta harus dibaca dalam konteks yang lebih luas, bukan hanya penataan di aspek nomenklatur, namun juga di aspek kelembagaan yang lainnya, yaitu: tata kelola kelembagaan, aspek aparatur, aspek sarana prarasana dan aspek pembiayaan. Rekomendasi penataan OPD konsekuensinya dirumuskan untuk masingmasing aspek tersebut, sebagai berikut:

1. Memberikan masukan/usulan ke Pemerintah Pusat mengenai perlunya melakukan revisi PP Nomor 18 Tahun 2016 tentang Organisasi Perangkat Daerah, khususnya mengenai variabel/instrumen pembentukan OPD, untuk mendasarkan lokalitas dan karakteristik masing-masing daerah. Bahwa dalam pemetaan OPD tidak bersifat asimetris, sehingga daerah mempunyai alternatif pilihan kelembagaan.

2. Di aspek struktur organisasi, perubahan bersifat inkremental, artinya tidak secara mendasar merubah nomenklatur kelembagaan pemerintah kota dan konteks kebutuhan kota Yogyakarta. Penataan kelembagaan OPD dilakukan secara komprehensif dengan mempertimbangkan aspek-aspek yuridis, filosofis, dan sosiologis. Dan tawaran nomenklatur dan tipologi OPD, di samping memperhatikan regulasi yang berlaku, juga mempertimbangkan kebutuhan dan konteks lokal Kota Yogyakarta.

3. Adaptasi struktur dengan model transisional yang terprogram, artinya, dengan struktur baru, semua bidang, bagian/sub-bidang/sub-bagian, diintegrasikan dengan model perkenalan fungsi-fungsi, tugas-tugas melalui orientasi secara profesional;

4. Kendala dasar Pemerintah Kota Yogyakarta adalah kecilnya jumlah aparat birokrasi yang bisa berakselerasi secara memadai untuk bisa menjalankan fungsi-fungsi kelembagaan. Penataan secara komprehensif diharapkan bisa meningkatkan performance kelembagaan pemerintahan kota, terutama dalam rangka untuk menangani masalah-masalah perkotaan yang semakin kompleks dan pengembangan pelayanan publik (dalam arti luas) yang lebih baik, sehingga bisa menjadikan Kota Yogyakarta sebagai lingkungan nyaman bagi warganya. Di samping itu juga perlu diatur mengenai kebijakan pengangkatan pegawai perorangan dengan output tertentu.

5. Keterbatasan sarana dan prasarana dengan melakukan stock opname, yaitu mengkonsentrasikan semua aset pada satu waktu untuk diidentifikasi, dikalkukasi, kemudian redistribusi dengan menyesuaikan kebutuhan OPD.

\section{Daftar Pustaka}

\section{Buku}

Bakker, Arnold B., and Wilmar B. Schaufeli. 2008. Positive Organizational Behavior: Engaged Employees in Flourishing Organizations, Journal of Organizational Behavior, J. Organiz. Behav. 29, 147-154 (2008), published online in Wiley Inter Science.

Cheema, G.S. dan Rondinelli, D.A. 1983. Decentralization and Development, 
Policy Implementation in Developing Country. USA : Sage Publications.

Fauzan, Haris. 2016. Perangkat daerah inovatif dan akselarasi inovasi pada Pemerintah Daerah.

Osborne, David and Ted Gaebler. 1995. Mewirausahakan Birokrasi, Jakarta: Pustaka Binaman Pressindo.

\section{Peraturan Perundangan}

Peraturan Pemerintah Nomor 41 Tahun 2007 Organisasi Perangkat Daerah. 23 Juli 2007. Lembaran Negara Republik Indonesia Tahun 2007 Nomor 89. Jakarta.

Peraturan Pemerintah Nomor 18 Tahun 2016 Perangkat Daerah. 15 Juni 2016. Lembaran Negara Republik Indonesia Tahun 2016 Nomor 114. Jakarta.

Peraturan Daerah Kota Yogyakarta Nomor 5 Tahun 2016 Pembentukan dan Susunan Perangkat Daerah Kota Yogyakarta. 20 Oktober 2016. Lembaran Daerah Kota Yogyakarta Tahun 2016 Nomor 5. Yogyakarta.

Peraturan Daerah Kabupaten Sleman Nomor 11 Tahun 2016 Pembentukan dan Susunan Perangkat Daerah Kabupaten Sleman. 13 September 2016. Lembaran Daerah Kabupaten Sleman Tahun 2016 Nomor 11. Sleman. 